\title{
Symposium review: Targeting antimicrobial defenses of the udder through an intrinsic cellular pathway ${ }^{1}$
}

\author{
Corwin D. Nelson, ${ }^{* 2}$ Kathryn E. Merriman, $\dagger$ Michael B. Poindexter, $\dagger$ Mercedes F. Kweh, $\dagger$ \\ and Leslie P. Blakely* \\ ${ }^{*}$ Department of Animal Sciences, and \\ †Animal Molecular and Cellular Biology Graduate Program, University of Florida, Gainesville 32611
}

\begin{abstract}
The bovine innate immune system has a strong repertoire of antimicrobial defenses to rapidly attack infectious pathogens that evade physical barriers of the udder. Exploration of the intracrine vitamin D pathway of bovine macrophages has improved understanding of the signals that initiate antimicrobial defenses that protect the udder. In the intracrine vitamin $\mathrm{D}$ pathway, pathogen recognition receptors upregulate $C Y P 27 B 1$ mRNA that encodes for the enzyme that converts 25-hydroxyvitamin $\mathrm{D}\left[25(\mathrm{OH}) \mathrm{D}_{3}\right]$ to the active vitamin D hormone, 1,25-dihydroxyvitamin $\mathrm{D}_{3}\left[1,25(\mathrm{OH})_{2} \mathrm{D}_{3}\right]$. The $1,25(\mathrm{OH})_{2} \mathrm{D}_{3}$, in turn, is generally known to increase antimicrobial activity and decrease inflammatory responses of immune cells. In cattle specifically, $1,25(\mathrm{OH})_{2} \mathrm{D}_{3}$ increases nitric oxide and $\beta$-defensin antimicrobial responses of bovine monocytes. Immune activation of the intracrine vitamin $\mathrm{D}$ pathway, including induction of inducible nitric oxide synthase and $\beta$-defensin gene expression by $1,25(\mathrm{OH})_{2} \mathrm{D}_{3}$, has been documented in the mammary glands of lactating dairy cows. Furthermore, intramammary 25(OH) $\mathrm{D}_{3}$ treatment decreased bacteria counts and indicators of mastitis severity in cows experimentally infected with Streptococcus uberis. We propose that vitamin $\mathrm{D}$ signaling in the udder contributes to containment of bacterial pathogens and inflammatory responses of the udder. Verification of vitamin D-mediated defenses of the mammary gland potentially provides a path for development of alternative solutions (i.e., nutritional, genetic, therapeutic) to increase mastitis resistance of dairy cows. Continued exploration of the intrinsic cellular pathways that specifically promote antimicrobial

\footnotetext{
Received June 30, 2017.

Accepted November 11, 2017.

${ }^{1}$ Presented as part of the Joint ADSA/National Mastitis Council

${ }^{2}$ Corresponding author: cdnelson@ufl.edu
} Symposium: Mastitis Control and Milk Quality Globally: Past, Present and an Amazing Future at the ADSA Annual Meeting, Pittsburgh, Pennsylvania, June 2017.
\end{abstract}

defenses of the udder, such as the vitamin D pathway, is needed to support mastitis control efforts for dairy cows.

Key words: macrophage, vitamin D, mastitis, dairy cow

\section{INTRODUCTION}

Mastitis is an inflammatory disease of the mammary gland most commonly caused by IMI of opportunistic bacterial pathogens that are ubiquitous in the environment of dairy cows (Ruegg, 2012). Inflammation of mammary tissue has long-term effects on productivity in addition to the immediate effects of inflammation on milk quality, productivity, and well-being of dairy cows. Prevention of IMI by proper care, management, and nutrition of dairy cows is the most effective approach for mastitis control; however, implementation of best management practices for mastitis prevention does not eliminate the occurrence of mastitis. Currently, antimicrobial drugs are the most effective therapeutic option available for treatment of IMI in dairy cows, but they have limited efficacy, require disposal of milk from treated cows, and raise concerns of antimicrobial resistance (Oliver and Murinda, 2012). Nutritional and therapeutic strategies that bolster antimicrobial defenses of the mammary gland offer a promising alternative for prevention and treatment of mastitis. Recent reports have documented a role for vitamin D in activation of antimicrobial defenses via intracrine and paracrine vitamin D signaling pathways (Liu et al., 2006; Nelson et al., 2010a,b). This paper will review evidence for vitamin D-mediated antimicrobial defenses and potential strategies to boost antimicrobial defenses of the udder through targeting the vitamin D pathway for the prevention and treatment of mastitis.

\section{INNATE IMMUNE DEFENSES OF THE UDDER}

Multiple defense systems are in place to defend the mammary gland against IMI. These include the 
physical barriers of the teat, constitutive cellular and humoral defenses, and activated cellular and humoral defenses (Sordillo and Streicher, 2002; Rainard and Riollet, 2006). Maintenance of the physical barriers of the teat by use of proper milking procedures and hygiene is by far the most important factor in prevention of IMI. Nevertheless, the humoral and cellular defenses of the gland provide a critical role in defense against opportunistic pathogens that inevitably evade the physical barriers of the teat. Macrophages and mammary epithelial cells provide innate surveillance of the mammary gland for bacterial pathogens. Upon pathogen recognition, they activate antimicrobial and inflammatory responses, which include antimicrobial peptides, lactoferrin, chemokines, and cytokines (Riollet et al., 2000; Schmitz et al., 2004). Neutrophils are recruited to the mammary gland if the resident defenses fail to prevent establishment of infection and play a critical role in resolution of IMI by release of granules loaded with antimicrobial peptides, phagocytosis, production of superoxides, and release of neutrophil extracellular traps (Lippolis et al., 2006; Rainard and Riollet, 2006). The lethal neutrophil activity, however, comes at a cost of damaged mammary tissue. Therefore, optimization of the resident defenses of the mammary gland against bacterial pathogens is desired to prevent establishment of IMI and subsequent need for massive neutrophil recruitment.

Macrophages and mammary epithelial cells provide innate surveillance of the mammary gland for pathogens via receptors such as toll-like receptor 2 (TLR-2), TLR-4, and TLR-5, which recognize lipoteichoic acids, LPS, and flagella, respectively (Kopp and Medzhitov, 2003; Ibeagha-Awemu et al., 2008). The pathogen recognition receptors initiate antimicrobial, cytokine, and inflammatory responses via intracellular signaling pathways. Certain pathways, such as the mitogen-activated protein kinase (MAPK) and nuclear factor $\kappa \mathrm{B}$ (NFאB) pathways, are primary pathways that prime immune functions and initiate transcription of genes involved in the immune response. Secondary pathways, such as prostaglandin, oxylipid, and vitamin D signaling pathways, are activated by MAPK or NFkB signaling and modulate TLR-induced antimicrobial and inflammatory responses (Schmitz et al., 2004; Liu et al., 2007a; Samuchiwal et al., 2017). The secondary pathways provide opportunities for specific modulation of innate immune responses via therapeutic or nutritional approaches (Ryman et al., 2017). Vitamin D signaling, in particular, has been identified as a key activator of antimicrobial defenses in human macrophages (Adams et al., 2007). Vitamin D signaling is activated in the bovine mammary gland during mastitis as part of the innate response to bacterial infection and enhances immune responses associated with antimicrobial defense in cattle (Nelson et al., 2010a; Lippolis et al., 2011; Merriman et al., 2017).

\section{VITAMIN D METABOLISM AND MECHANISM OF FUNCTION}

Vitamin D was originally discovered almost a century ago as a factor in butterfat that prevented rickets (McCollum et al., 1922). In the years to follow, it was also found to be synthesized in the skin exposed to sunlight and to be critically involved in calcium homeostasis. Long before the discovery that vitamin D prevented rickets, sunlight and cod liver oil, which are good sources of vitamin D, were prescribed as a therapy for tuberculosis in human patients (Cassidy and Martineau, 2014). As it turns out, vitamin D supports antimicrobial mechanisms of macrophages via an intracrine antimicrobial pathway (Liu et al., 2006).

Vitamin $\mathrm{D}_{3}$ primarily exerts biological activity upon enzymatic conversion to a potent ligand for intracellular vitamin D receptors (VDR; Haussler et al., 2013). Vitamin $\mathrm{D}_{3}$ undergoes 2 successive hydroxylation steps to become a biologically active molecule as depicted in Figure 1, a process that is very tightly controlled. First, vitamin $\mathrm{D}_{3}$ is hydroxylated to 25-hydroxyvitamin $\mathrm{D}_{3}\left[\left(25(\mathrm{OH}) \mathrm{D}_{3}\right]\right.$ by cytochrome $\mathrm{P} 450$ enzymes CYP2J2, CYP2R1, CYP27A1, and CYP3A4 in the liver (Jones et al., 2014). Conversion of vitamin $\mathrm{D}_{3}$ to $25(\mathrm{OH}) \mathrm{D}_{3}$ is not tightly regulated and concentrations of $25(\mathrm{OH}) \mathrm{D}_{3}$ circulating in blood are relatively stable over time (Sommerfeldt et al., 1983). Next, the $25(\mathrm{OH}) \mathrm{D}_{3}$ metabolite is converted to 1,25-dihydroxyvitamin $\mathrm{D}_{3}\left[1,25(\mathrm{OH})_{2} \mathrm{D}_{3}\right]$, the biologically active metabolite, by the cytochrome P450 1 $\alpha$-hydroxylase enzyme, CYP27B1. Both $25(\mathrm{OH}) \mathrm{D}_{3}$ and $1,25(\mathrm{OH})_{2} \mathrm{D}_{3}$ are inactivated by CYP24A1, another cytochrome P50 enzyme with 24-hydroxylase activity. The ratio of CYP27B1 to CYP24A1 is a major determinant of vitamin D's physiological actions. The vast majority of CYP27B1 activity is in the kidneys, which is homeostatically controlled by an endocrine mechanism as a function of calcium and phosphorus concentrations in blood (Horst et al., 2005). The CYP24A1 is strongly induced by $1,25(\mathrm{OH})_{2} \mathrm{D}_{3}$ in target tissues such as the intestines and kidneys to provide feedback control of $1,25(\mathrm{OH})_{2} \mathrm{D}_{3}$ concentrations in target tissues. Immune cells also have CYP27B1 and CYP24A1 activity that is dictated by immune activation (Nelson et al., 2010b). The immune control of $1,25(\mathrm{OH})_{2} \mathrm{D}_{3}$ metabolism in infected tissues is a critical feature of vitamin D-mediated immunity. 
The biological function of $1,25(\mathrm{OH})_{2} \mathrm{D}_{3}$ is carried out predominantly through the VDR. The VDR is a nuclear hormone receptor that forms a heterodimer with the retinoid X receptor (Haussler et al., 2013). The DNA binding domains of the VDR-RXR heterodimer bind to accessible vitamin D response elements (VDRE) in the promoter or enhancer regions of vitamin D-responsive genes (Haussler et al., 2013). The VDRE are short tandem sequences of DNA typically characterized as direct repeats separated by $3 \mathrm{bp}$. The VDR has widespread influence in the mammalian genome. The human and murine genomes are predicted to have almost 1,000 genes with potential VDRE (Wang et al., 2005) in the proximal promoter region. Furthermore, using next-generation sequencing of chromatin immune-precipitated with ligand-activated VDR, researchers have shown the VDR influences gene transcription by binding VDRE in distal enhancer regions (Pike and Meyer, 2014). Discovery of VDR's genomic actions in humans and rodents in recent years has greatly improved knowledge of the biological actions of $1,25(\mathrm{OH})_{2} \mathrm{D}_{3}$. Accordingly, identification of genes influenced by the VDR in the bovine genome will improve knowledge of the biological actions of $1,25(\mathrm{OH})_{2} \mathrm{D}_{3}$ in cattle, and ultimately lead to more accurate therapeutic and nutritional strategies aimed at improving dairy cow health and performance.

\section{CONVERGENCE OF VITAMIN D AND ANTIMICROBIAL PATHWAYS}

A seminal paper published by Liu et al. (2006) documented the link between vitamin $\mathrm{D}$ and antimicrobial pathways in macrophages. Previously, several reports documented that IFN- $\gamma$ - and LPS-stimulated macrophages produced $1,25(\mathrm{OH})_{2} \mathrm{D}_{3}$ and demonstrated an immunomodulatory role for $1,25(\mathrm{OH})_{2} \mathrm{D}_{3}$. Wang et al. (2004) and Gombart et al. (2005) reported that $1,25(\mathrm{OH})_{2} \mathrm{D}_{3}$ increased bactericidal activity of human phagocyte and epithelial cell cultures by increasing cathelicidin antimicrobial peptide expression. In their reports, they demonstrated the presence of multiple VDRE in the human cathelicidin gene promoter. The report by Liu et al. (2006) solidified the biological significance of the $1,25(\mathrm{OH})_{2} \mathrm{D}_{3}$ production and activity in macrophages; they demonstrated that activation of an intracrine vitamin D pathway was an integral element in the macrophage defense against bacterial infection. In the vitamin D-mediated antimicrobial mechanism Liu et al. (2006) described, TLR2 activation of macrophages induced expression of CYP27B1 and VDR in macrophages. The $1,25(\mathrm{OH})_{2} \mathrm{D}_{3}$ produced in macrophages inhibited intracellular growth of Mycobacterium tuberculosis by increasing production of the cathelicidin

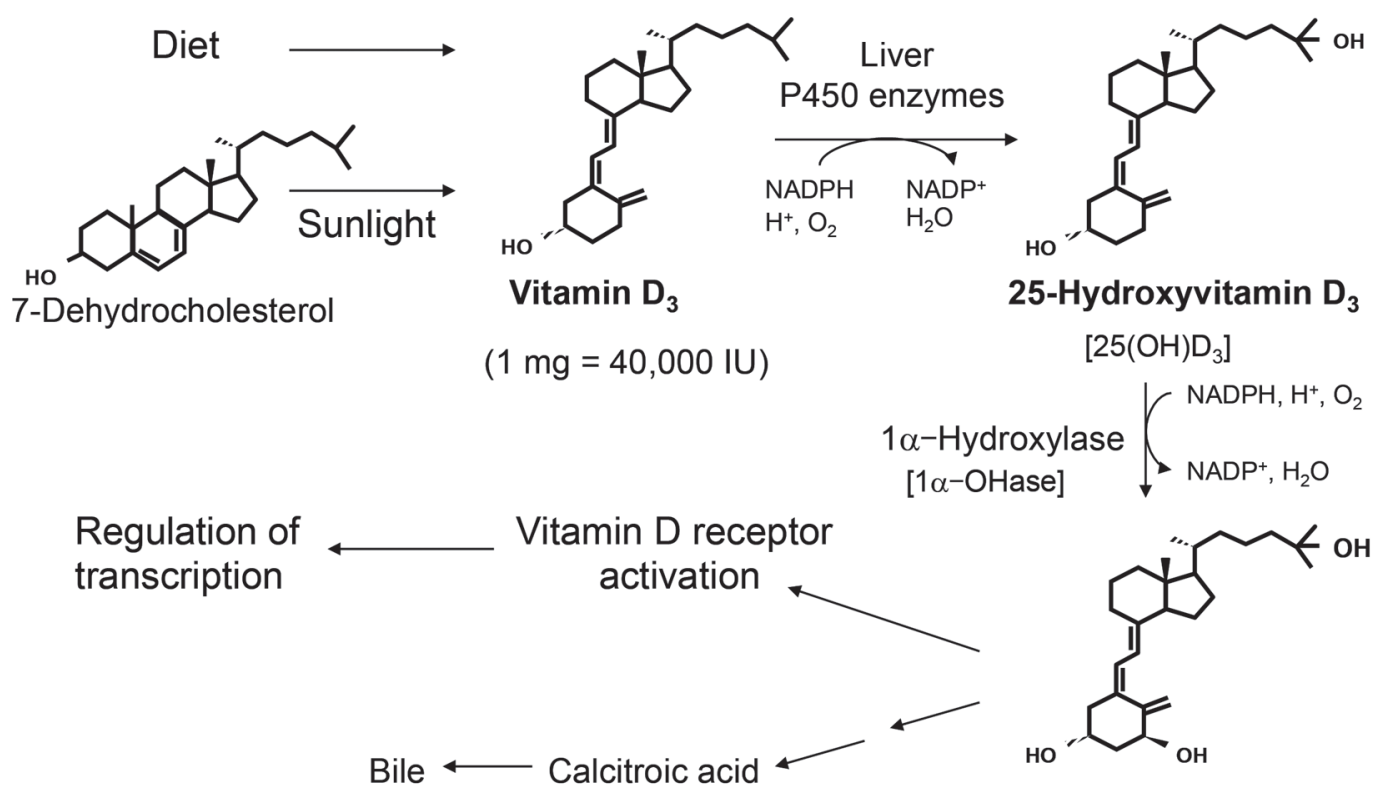

1 $\alpha, 25$-Dihydroxyvitamin $\mathrm{D}_{3}$ $\left[1,25(\mathrm{OH})_{2} \mathrm{D}_{3}\right]$

Figure 1. Vitamin D metabolic pathway. Two natural sources exist for vitamin D in cattle, vitamin $\mathrm{D}_{2}$ and vitamin $\mathrm{D}_{3}$. Both forms contribute to the overall signaling events of vitamin $\mathrm{D}$, but vitamin $\mathrm{D}_{3}$ is the predominant form in cattle. Vitamin $\mathrm{D}_{3}$ is converted to 25 -hydroxyvitamin $\mathrm{D}_{3}$ by 25 -hydroxylases in the liver, then 25 -hydroxyvitamin $\mathrm{D}_{3}$ is converted to 1,25 -dihydroxyvitamin $\mathrm{D}_{3}$ by the 25 -hydroxyvitamin $\mathrm{D}$ $1 \alpha$-hydroxylase, CYP27B1. The $1,25(\mathrm{OH})_{2} \mathrm{D}_{3}$ is the ligand for the vitamin $\mathrm{D}$ receptor. The 25-hydroxyvitamin D 24-hydroxylase, CYP24A1, is induced by $1,25(\mathrm{OH})_{2} \mathrm{D}_{3}$ and provides feedback of vitamin $\mathrm{D}$ signaling by catabolism of $25(\mathrm{OH}) \mathrm{D}_{3}$ and $1,25(\mathrm{OH})_{2} \mathrm{D}_{3}$. 


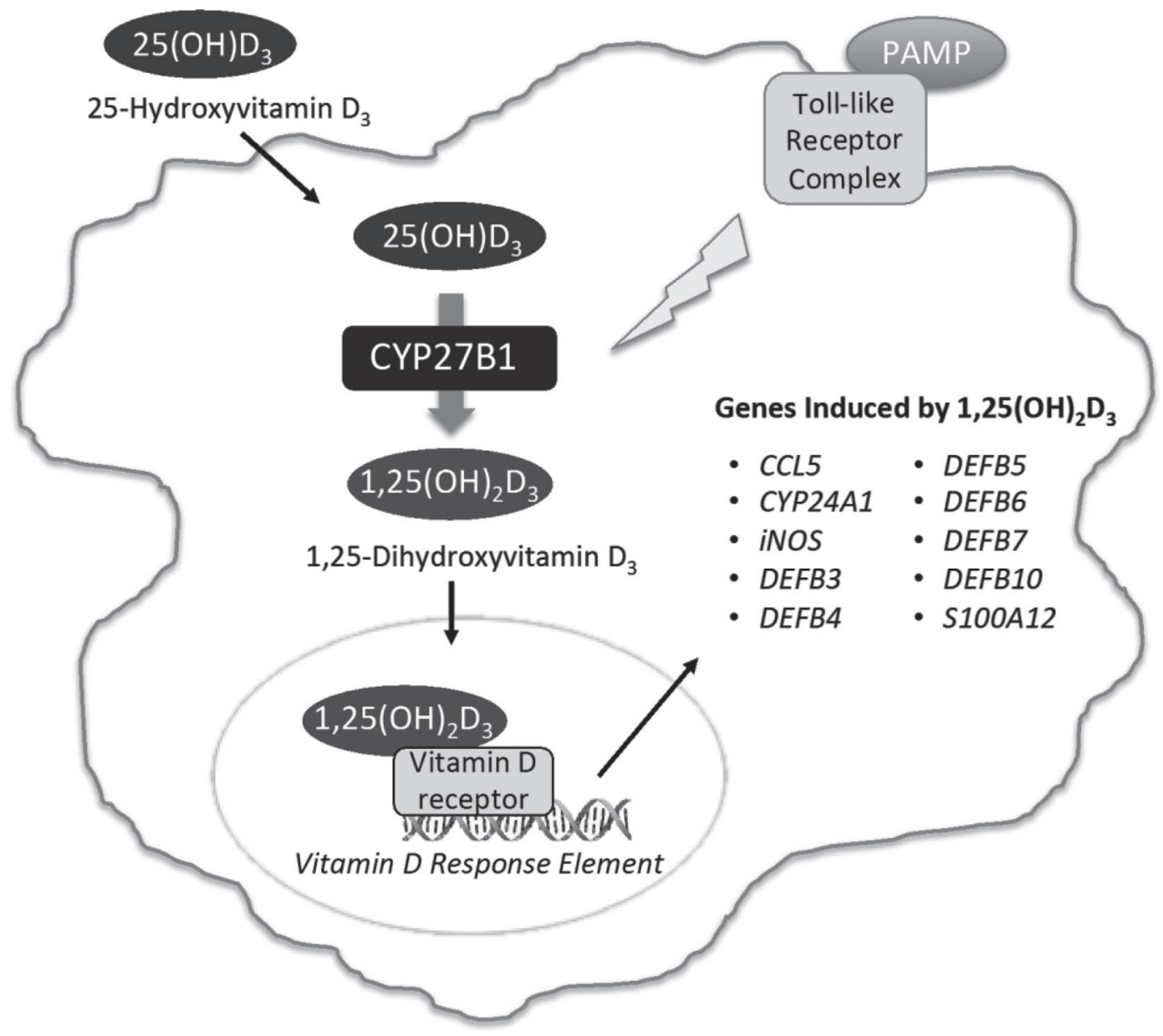

Figure 2. Macrophage intracrine vitamin D pathway. Toll-like receptor signaling in response to pathogen associated molecular patterns (PAMP) induces the CYP27B1 enzyme that converts $25(\mathrm{OH}) \mathrm{D}_{3}$ to $1,25(\mathrm{OH})_{2} \mathrm{D}_{3}$, the biologically active metabolite. The $1,25(\mathrm{OH})_{2} \mathrm{D}_{3}$ activates the vitamin $\mathrm{D}$ receptor, a nuclear hormone receptor that functions as a transcription factor. The $1,25(\mathrm{OH})_{2} \mathrm{D}_{3}$ produced in monocytes induces expression of genes for inducible nitric oxide synthase (iNOS), $\beta$-defensin 3 (DEFB3), DEFB4, DEFB6, DEFB7, DEF10, chemokine (C-C motif) 5 (CCL5), and calcium binding protein S100A12.

antimicrobial peptide, LL-37. Consequently, macrophages cultured in $25(\mathrm{OH}) \mathrm{D}_{3}$-deficient media were less effective in controlling $M$. tuberculosis growth compared with macrophages cultured in $25(\mathrm{OH}) \mathrm{D}$-supplemented media. The discovery of this vitamin D-mediated antimicrobial pathway in human macrophages sparked interest for the role of vitamin $\mathrm{D}$ in bacterial diseases of cattle. The ensuing investigations have led to opportunities to enhance antimicrobial defenses of the udder through the vitamin D pathway.

In cattle, innate immune activation of the vitamin $\mathrm{D}$ pathway in macrophages contributes to activation of antimicrobial defenses that are potentially relevant for mastitis in dairy cows (Figure 2). Activation of bovine monocytes with LPS and peptidoglycan, molecules associated with common mastitis pathogens, increased CYP27B1 gene expression by more than 2 -fold in stimulated monocytes compared with non- stimulated monocytes (Nelson et al., 2010b). Stimulation of monocytes also resulted in potent inhibition of CYP24A1 gene expression in monocytes treated with $1,25(\mathrm{OH})_{2} \mathrm{D}_{3}$ (Nelson et al., 2010b). Induction of $C Y P 27 B 1$ and inhibition of $C Y$ P24A1 in monocytes by bacterial-associated molecules represents the possible importance of $1,25(\mathrm{OH})_{2} \mathrm{D}_{3}$ metabolism in the innate immune response to bacterial infection.

A plethora of immunomodulatory actions have been reported for $1,25(\mathrm{OH})_{2} \mathrm{D}_{3}$ in several species and, in general, include induction of antimicrobial mechanisms and suppression of inflammation as reviewed extensively by others (Adams et al., 2007; Baeke et al., 2010). The immunomodulatory actions of $1,25(\mathrm{OH})_{2} \mathrm{D}_{3}$, however, are somewhat species specific (Nelson et al., 2012). For instance, $1,25(\mathrm{OH})_{2} \mathrm{D}_{3}$ increases bactericidal activity of human macrophages by increasing production of cathelicidin and $\beta$-defensin antimicrobial peptides (Liu et 
al., 2007b, 2009). In contrast, vitamin D signaling does not induce murine cathelicidin or $\beta$-defensin expression and, overall, does not promote antimicrobial activity of murine macrophages. Likewise, cattle have several genes encoding for cathelicidin antimicrobial peptides, but none were upregulated by $1,25(\mathrm{OH})_{2} \mathrm{D}_{3}$, which coincides with reports that $1,25(\mathrm{OH})_{2} \mathrm{D}_{3}$-induction of cathelicidin is primate-specific (Gombart et al., 2009; Nelson et al., 2010b). Instead, vitamin D signaling is a potent stimulator of nitric oxide production by bovine monocytes. Expression of $i N O S$ and nitric oxide production were positively correlated with concentrations of $25(\mathrm{OH}) \mathrm{D}_{3}$ added to the cultures of LPS-stimulated monocytes from lactating Holstein cows (Nelson et al., 2010b). In the same way, mRNA transcripts for chemokine (C-C motif) ligand 5 (CCL5, also known as RANTES), $\beta$-defensin 3 (DEFB3), DEFB4, DEFB6, $D E F B$ \%, and $D E F B 10$ in LPS-stimulated monocytes were increased by $25(\mathrm{OH}) \mathrm{D}_{3}$ added to the culture medium (Merriman et al., 2015). The functional outcome of each of these responses to vitamin D signaling still need to be explored, but the known responses suggest vitamin $\mathrm{D}$ signaling in the bovine immune system has implications for defense of the udder.

Our primary hypothesis is that vitamin D-mediated upregulation of nitric oxide and $\beta$-defensin responses in cattle serves to enhance bactericidal activity of macrophages. Nitric oxide reacts with superoxide molecules in phagolysosomes to form reactive nitrogen species, such as peroxynitrite, which contribute to the killing of bacteria in macrophages (Bogdan, 2001). Inhibition of nitric oxide production in bovine macrophages also impaired killing of Mycobacterium bovis (Esquivel-Solis et al., 2013). Furthermore, the $\beta$-defensin genes upregulated by $1,25(\mathrm{OH})$ in bovine monocytes encode for small cationic peptides that have potent antimicrobial activity against gram-positive and gram-negative bacteria (Selsted et al., 1993). Thus, vitamin D-mediated nitric oxide and $\beta$-defensin production seemingly provides an opportunity for targeted enhancement of endogenous bactericidal molecules in macrophages of the mammary gland.

The main outcome of monocyte $1,25(\mathrm{OH})_{2} \mathrm{D}_{3}$ production, however, may not be bactericidal activity. For example, nitric oxide also functions as a key signaling molecule in the innate immune response to pathogens through protein nitrosylation and redox signaling (Bogdan, 2001). Several of the $\beta$-defensins also have chemotactic properties and increased attraction of dendritic cells (Mackenzie-Dyck et al., 2011). Similarly, CCL5, which is induced by $1,25(\mathrm{OH})_{2} \mathrm{D}_{3}$ in bovine monocytes, increased attraction and activation of monocytes (Hussen et al., 2014). In these ways, the functional outcomes of $1,25(\mathrm{OH})_{2} \mathrm{D}_{3}$-induced nitric oxide production and expression of $\beta$-defensin and CCL5 genes largely remain unknown. They are potential mechanisms to be explored for clinical outcomes of vitamin D in cattle, but at this point, they merely serve as biomarkers for vitamin $\mathrm{D}$ pathway activity in the bovine immune system.

With regard to other cells relevant to defense of the mammary gland, mammary epithelial cells and neutrophils also express the VDR and are sensitive to $1,25(\mathrm{OH})_{2} \mathrm{D}_{3}$ treatment (Merriman et al., 2015). Treatment of bovine LPS-stimulated mammary epithelial cell and neutrophil cultures with $1,25(\mathrm{OH})_{2} \mathrm{D}_{3}$ increased iNOS gene expression somewhat similarly to monocytes (Merriman et al., 2015). Merriman et al. (2015) also reported that mammary epithelial cell DEFB4 mRNA expression was increased by $1,25(\mathrm{OH})_{2} \mathrm{D}_{3}$ treatment, but DEFB3, DEFB6, DEFB \%, and DEFB10 in mammary epithelial cells and neutrophils were either not affected or slightly decreased by $1,25(\mathrm{OH})_{2} \mathrm{D}_{3}$ treatment. Téllez-Pérez et al. (2012), reported that vitamin $\mathrm{D}_{3}$ treatment increased lingual antimicrobial peptide, a member of the $\beta$-defensin gene family, DEFB10 and S100A7 expression, and inhibited Staphylococcus aureus invasion of bovine mammary epithelial cells. Similarly, Yue et al. (2017) reported that $25(\mathrm{OH}) \mathrm{D}_{3}$ treatment of mammary epithelial cell cultures inhibited Staphylococcus aureus invasion. Although the evidence specific to cattle is still quite limited, the aforementioned reports provide initial evidence of the potential contribution of vitamin D to antimicrobial defenses of mammary immune cells.

\section{VITAMIN D IN CONTROL OF INFLAMMATION}

In addition to potential contribution of vitamin $\mathrm{D}$ signaling to antimicrobial activity, it may serve to protect the udder from mastitis by containment of inflammatory responses. The suppressive effects of $1,25(\mathrm{OH})_{2} \mathrm{D}_{3}$ on inflammation are well-documented in models of inflammatory diseases and are evident in rodents, humans, and cattle (Nelson et al., 2012; Cannell et al., $2015)$. With regard to cattle, $1,25(\mathrm{OH})_{2} \mathrm{D}_{3}$ treatment of antigen-stimulated mononuclear cell cultures decreased $\mathrm{T}$ cell proliferation, IFN- $\gamma$ production, and IL-17F expression (Waters et al., 2001; Nelson et al., 2011). The decreased IFN- $\gamma$ and IL-17F responses by $1,25(\mathrm{OH})_{2} \mathrm{D}_{3}$ treatment of bovine mononuclear cell cultures suggest a potential role for vitamin D signaling in containment of excessive T cell-mediated inflammation. Such a role has been documented in vivo with rodent models of $\mathrm{T}$ cell-mediated inflammation (Bruce et al., 2011; Mayne et al., 2011; Nashold et al., 2013).

Perhaps more relevant for protection of the mammary gland, but yet unexplored in cattle, are the pro- 
tective actions of vitamin D from endotoxin-induced damage of tissues. Production of pro-inflammatory cytokines IL-6, IL-8, and TNF- $\alpha$ in response to LPS were decreased by $1,25(\mathrm{OH})_{2} \mathrm{D}_{3}$ treatment of cell cultures (Zhang et al., 2012; Hoe et al., 2016). Similarly, bovine mammary epithelial cell responsiveness to LPS stimulation is dampened somewhat by $1,25(\mathrm{OH})_{2} \mathrm{D}_{3}$ treatment (Merriman et al., 2015). Additionally, tightjunction integrity upon LPS challenge was improved by $1,25(\mathrm{OH})_{2} \mathrm{D}_{3}$ in intestinal epithelial cell cultures (Chen et al., 2015a). Dietary vitamin $\mathrm{D}_{3}$ also protected integrity of the intestinal epithelium in response to dextran sulfate sodium-induced inflammation in mice (Wang et al., 2017). The mechanisms of vitamin D-mediated suppression of inflammation include vitamin D-meditated suppression of TLR expression, or interference with NF- $\kappa \mathrm{B}$ and MAPK signaling pathways (Sadeghi et al., 2006; Zhang et al., 2012; Chen et al., 2015b). Vitamin $\mathrm{D}$ signaling also is reported to alleviate cellular damage caused by oxidative stress by increasing antioxidant activity (Ferret et al., 2000). Each of these mechanisms warrants further investigation in regards to mastitis as protection of the mammary epithelium is critical for resolution of bacterial infection and productivity of the gland. As noted above, pathogen recognition receptor signaling, which initiates the inflammatory response, also stimulates $1,25(\mathrm{OH})_{2} \mathrm{D}_{3}$ synthesis in immune cells; perhaps the suppressive effect of $1,25(\mathrm{OH})_{2} \mathrm{D}_{3}$ on inflammatory responses serves as a feedback mechanism to limit excessive inflammation.

\section{VITAMIN D SIGNALING DURING MASTITIS}

Activation of the intracrine vitamin D pathway of macrophages described above has been documented in the mammary gland. Expression of the vitamin D pathway genes CYP27B1, CYP24A1, and VDR was highly upregulated in mammary tissue and milk somatic cells from glands experimentally challenged with intramammary Streptococcus uberis compared with tissue and cells from healthy glands or peripheral blood leukocytes (Nelson et al., 2010a). The CYP27B1 was upregulated more than 300-fold in somatic cells from the infected glands compared with somatic cells from healthy glands. The CYP27B1 expression also was more abundant in CD14-positive cells, a marker of macrophages, than CD14-negative cells in the infected mammary glands. Similarly, intramammary LPS challenge stimulated CYP27B1, CYP24A1, and VDR expression in milk somatic cells within $4 \mathrm{~h}$ postchallenge (Merriman et al., 2015). In the LPS model, however, abundance of CYP27B1 was similar in macrophages and neutrophils in the challenged glands. In both experiments, the increased CYP24A1 expression, which is highly upregu- lated by $1,25(\mathrm{OH})_{2} \mathrm{D}_{3}$, in theory indicates that induction of $C Y P 27 B 1$ expression in mammary phagocytes led to increased production of $1,25(\mathrm{OH})_{2} \mathrm{D}_{3}$. That data are in agreement with those of in vitro experiments (Nelson et al., 2010b) and provide further indication that an intracrine vitamin D signaling mechanism is activated as part of the innate immune response.

More recently, the effects of $1,25(\mathrm{OH})_{2} \mathrm{D}_{3}$ on expression of potential vitamin $\mathrm{D}$ target genes in mammary immune cells were investigated. Merriman et al. (2017) reported the specific effects of $1,25(\mathrm{OH})_{2} \mathrm{D}_{3}$ on regulation of gene expression in the mammary gland. Contralateral mammary glands of healthy cows received $10 \mu \mathrm{g}$ of $1,25(\mathrm{OH})_{2} \mathrm{D}_{3}$ or placebo treatment and gene expression was evaluated in milk somatic cells as an indicator of the effects of $1,25(\mathrm{OH})_{2} \mathrm{D}_{3}$ treatment. Expression of CYP24A1, as expected, was highly upregulated in cells from $1,25(\mathrm{OH})_{2} \mathrm{D}_{3}$-treated glands within a few hours, but $C Y P^{2} 4 A 1$ was not increased in placebo-treated glands. Expression of $i N O S$ and DEFB7 also was upregulated in milk somatic cells from the $1,25(\mathrm{OH})_{2} \mathrm{D}_{3^{-}}$ treated glands compared with cells from the control glands. Furthermore, expression of iNOS was greater in macrophages from the $1,25(\mathrm{OH})_{2} \mathrm{D}_{3}$-treated glands compared with macrophages from the placebo-treated glands. The other $\beta$-defensins induced by $1,25(\mathrm{OH})_{2} \mathrm{D}_{3}$ in vitro, and $C C L 5$, however, were not affected by the intramammary $1,25(\mathrm{OH})_{2} \mathrm{D}_{3}$ treatment.

In a second experiment, Merriman et al. (2017) reported the effects of intramammary $1,25(\mathrm{OH})_{2} \mathrm{D}_{3}$ treatment on indicators of mammary immunity during subclinical mastitis. Mammary glands with naturally occurring subclinical mastitis were treated with $10 \mu \mathrm{g}$ of $1,25(\mathrm{OH})_{2} \mathrm{D}_{3}$ or placebo treatments $(\mathrm{n}=11 /$ treatment) every $12 \mathrm{~h}$ for $48 \mathrm{~h}$. Expression of $C Y P 24 A 1$, iNOS, DEFB4, and DEFB' were upregulated in milk somatic cells from glands treated with $1,25(\mathrm{OH})_{2} \mathrm{D}_{3}$ compared with placebo. Although concentrations of $1,25(\mathrm{OH})_{2} \mathrm{D}_{3}$ were slightly elevated in cows treated with intramammary $1,25(\mathrm{OH})_{2} \mathrm{D}_{3}$ compared with the placebo treatment, concentrations of calcium in serum were not affected. The experiment was not designed to determine effects of $1,25(\mathrm{OH})_{2} \mathrm{D}_{3}$ treatment on resolution of infection, and no differences in resolution of infection were observed, but the experiment did affirm the influence of $1,25(\mathrm{OH})_{2} \mathrm{D}_{3}$ on expression of $i N O S$ and $\beta$-defensin genes observed in monocyte cultures. Again, the functional outcomes of increased $i N O S$ and $\beta$-defensin expression have yet to be determined, and merely serve as biomarkers for vitamin D pathway activity; however, induction of $i N O S$ and $\beta$-defensin genes by $1,25(\mathrm{OH})_{2} \mathrm{D}_{3}$ in mammary immune cells provides additional evidence to explore their role in defense against bacterial infection. 
The potential effect of the vitamin D pathway in defense of the mammary gland against bacterial infection was demonstrated in experiments reported by Lippolis et al. (2011). In their experiment, 10 lactating Holstein cows received $100 \mu \mathrm{g}$ of $25(\mathrm{OH}) \mathrm{D}_{3}$ intramammary or placebo treatments $(\mathrm{n}=5 /$ treatment $)$ at the time of intramammary $S$. uberis challenge and again every 12 $\mathrm{h}$ for $5 \mathrm{~d}$. Cows typically develop clinical mastitis in 48 to $72 \mathrm{~h}$ after bacterial challenge in the model of S. uberis mastitis used in the experiment. Cows that received intramammary $25(\mathrm{OH}) \mathrm{D}_{3}$ treatments had over 1,000 fewer colony forming units of $S$. uberis per milliliter of milk at 48 and $72 \mathrm{~h}$ after challenge compared with placebo-treated cows. The $25(\mathrm{OH}) \mathrm{D}_{3}$-treated cows also tended to have lower rectal temperatures, lower concentrations of bovine serum albumin in milk, and less severe decreases in milk production and feed intake compared with placebo-treated cows. The intramammary $25(\mathrm{OH}) \mathrm{D}_{3}$ did not affect concentrations of $25(\mathrm{OH})$ $\mathrm{D}_{3}$ in serum, which discredits a role for renal vitamin $\mathrm{D}$ metabolism in response to treatment. The authors suggest that intramammary $25(\mathrm{OH}) \mathrm{D}_{3}$ decreased severity of mastitis via the actions of the intracrine vitamin $\mathrm{D}$ pathway of macrophages. Alternatively, the $25(\mathrm{OH}) \mathrm{D}_{3}$ concentrations achieved in the treated glands may have been sufficient to activate the VDR in immune cells without prior conversion to $1,25(\mathrm{OH})_{2} \mathrm{D}_{3}$.

Although the evidence is still quite limited, the data from the experiments above provide evidence in support of vitamin D's potential role in defense of the mammary gland. Based on our current knowledge of how vitamin $\mathrm{D}$ acts in the bovine immune system, we hypothesize that innate sensing of bacterial pathogens triggers conversion of $25(\mathrm{OH}) \mathrm{D}_{3}$ to $1,25(\mathrm{OH})_{2} \mathrm{D}_{3}$ in the infected mammary gland, which subsequently improves elimination of the pathogen by phagocytes via upregulation of nitric oxide and $\beta$-defensin antimicrobial mechanisms. Further, or alternative, protection may result by vitamin D-mediated suppression of inflammation and maintenance of the mammary epithelial barrier.

Certainly, much work is still needed to validate the accuracy and relevance of our hypothesis of vitamin D's role in defense of the mammary gland. Much of the evidence currently relies on expression of vitamin D pathway genes, which does not reveal actual metabolism of vitamin $\mathrm{D}$, but is the extent of what is feasible for the time being because of the difficulty in accurate measurements of the vitamin $\mathrm{D}$ metabolites in tissues and milk. Furthermore, the effects of $1,25(\mathrm{OH})_{2} \mathrm{D}_{3}$ on immune cells of the mammary gland are limited to expression of previously identified target genes, and although vitamin D-dependent antimicrobial activity is documented in human macrophages, it has not been documented in bovine macrophages.
The many variables that influence mastitis, such as pathogen, stage of lactation, or breed composition are not accounted for as well. The experiments described above used Holstein cows in mid to late lactation. The immunosuppression and changes in renal vitamin D metabolism that occur postpartum, when the risk for mastitis is greatest, may lessen the effectiveness of vitamin D signaling in the immune cells of the mammary gland. The immunomodulatory role of vitamin D may not be as influential in other breeds either, as differences in magnitude of nitric oxide production among dairy breeds have been reported (Gibson et al., 2016). Finally, the effectiveness of antimicrobial pathways activated by $1,25(\mathrm{OH})_{2} \mathrm{D}_{3}$ in mammary immune cells, if indeed functional, may not apply to all mastitis pathogens. For example, although intramammary $25(\mathrm{OH})$ $\mathrm{D}_{3}$ treatment was shown to provide some protection against experimental $S$. uberis infection, the actions of vitamin $\mathrm{D}$ signaling in the immune system may not provide the same type of benefit for E. coli infection, which has been associated with a more rapid and severe onset of mastitis (Bannerman et al., 2004). Hopefully, continued research regarding these unknowns will elucidate the hypothetical role of vitamin D in defense of the mammary gland.

\section{CONCLUSIONS AND FUTURE DIRECTIONS}

The published literature indicates a role for vitamin $\mathrm{D}$ in activation of antimicrobial defenses via induction of vitamin D signaling in immune cells. Evidence from experiments with bovine mastitis have provided relevance for vitamin D-mediated antimicrobial defenses in the mammary gland by showing that vitamin D signaling is activated during mastitis and intramammary vitamin D-based treatments improved indicators of antimicrobial activity. The requirement for vitamin D signaling in the antimicrobial response and the mechanisms of vitamin D-mediated immune responses, however, remain undefined and offer promising avenues for future research. Improved recommendations for vitamin $\mathrm{D}_{3}$ nutrition of dairy cows are potentially the most immediate and practical implication of elucidating a role for vitamin $\mathrm{D}$ signaling in the immune system. Currently, dairy cows in the United States are typically supplemented with vitamin $\mathrm{D}_{3}$ at or above the NRC recommendation of 21,000 IU/d (NRC, 2001). The NRC recommendation for dietary vitamin $D_{3}$ is adequate for calcium homeostasis but may not achieve the full potential of the immune system. Supplemental vitamin $D_{3}$ is inexpensive, so maximizing vitamin $D$ mediated antimicrobial defenses through dietary vitamin $\mathrm{D}_{3}$ has minimal cost. Tolerable upper limits need to be established, however, as excessive supplemental 
vitamin $\mathrm{D}_{3}$ can be toxic. In addition to implications of vitamin $\mathrm{D}_{3}$ nutrition, additional research is needed to understand the functional outcomes of vitamin Dmediated immune responses. Whether upregulation of nitric oxide and $\beta$-defensin production by vitamin $\mathrm{D}$ signaling leads to enhanced antimicrobial activity and the extent of genes targeted by the activated vitamin D receptor in immune cells are uncertain. We anticipate efforts to elucidate of the role of vitamin D signaling in defense of the mammary gland will prove fruitful in minimizing the effect of mastitis in dairy cows.

\section{ACKNOWLEDGMENTS}

The work is supported by funds from the Florida Agriculture Experiment Station (Gainesville) and Southeast Milk Check-Off (Belleview, FL).

\section{REFERENCES}

Adams, J. S., P. T. Liu, R. Chun, R. L. Modlin, and M. Hewison. 2007. Vitamin D in defense of the human immune response. Ann. N. Y. Acad. Sci. 1117:94-105.

Baeke, F., T. Takiishi, H. Korf, C. Gysemans, and C. Mathieu. 2010. Vitamin D: Modulator of the immune system. Curr. Opin. Pharmacol. 10:482-496.

Bannerman, D. D., M. J. Paape, W. R. Hare, and J. C. Hope. 2004. Characterization of the bovine innate immune response to intramammary infection with Klebsiella pneumoniae. J. Dairy Sci. $87: 2420-2432$

Bogdan, C. 2001. Nitric oxide and the immune response. Nat. Immunol. 2:907-916.

Bruce, D., S. Yu, J. H. Ooi, and M. T. Cantorna. 2011. Converging pathways lead to overproduction of IL-17 in the absence of vitamin D signaling. Int. Immunol. 23:519-528.

Cannell, J. J., W. B. Grant, and M. F. Holick. 2015. Vitamin D and inflammation. Dermatoendocrinology 6:e983401.

Cassidy, J. P., and A. R. Martineau. 2014. Innate resistance to tuberculosis in man, cattle and laboratory animal models: Nipping disease in the bud? J. Comp. Pathol. 151:291-308.

Chen, S. W., P. Y. Wang, J. Zhu, G. W. Chen, J. L. Zhang, Z. Y. Chen, S. Zuo, Y. C. Liu, and Y. S. Pan. 2015a. Protective effect of 1,25-dihydroxyvitamin $\mathrm{D}_{3}$ on lipopolysaccharide-induced intestinal epithelial tight junction injury in caco-2 cell monolayers. Inflammation 38:375-383.

Chen, Y. H., Z. Yu, L. Fu, H. Wang, X. Chen, C. Zhang, Z. M. Lv, and D. X. Xu. 2015b. Vitamin $\mathrm{D}_{3}$ inhibits lipopolysaccharide-induced placental inflammation through reinforcing interaction between vitamin D receptor and nuclear factor kappa B p65 subunit. Sci. Rep. 5:10871.

Esquivel-Solis, H., A. J. Vallecillo, A. Benitez-Guzman, L. G. Adams, Y. Lopez-Vidal, and J. A. Gutierrez-Pabello. 2013. Nitric oxide not apoptosis mediates differential killing of Mycobacterium bovis in bovine macrophages. PLoS One 8:e63464.

Ferret, P. J., E. Soum, O. Negre, E. E. Wollman, and D. Fradelizi. 2000. Protective effect of thioredoxin upon NO-mediated cell injury in THP1 monocytic human cells. Biochem. J. 346:759-765.

Gibson, A. J., S. Woodman, C. Pennelegion, R. Patterson, E. Stuart, N. Hosker, P. Siviter, C. Douglas, J. Whitehouse, W. Wilkinson, S. A. Pegg, B. Villarreal-Ramos, and D. Werling. 2016. Differential macrophage function in Brown Swiss and Holstein Friesian cattle. Vet. Immunol. Immunopathol. 181:15-23.

Gombart, A. F., N. Borregaard, and H. P. Koeffler. 2005. Human cathelicidin antimicrobial peptide (CAMP) gene is a direct target of the vitamin $\mathrm{D}$ receptor and is strongly up-regulated in myeloid cells by 1,25-dihydroxyvitamin $\mathrm{D}_{3}$. FASEB J. 19:1067-1077.

Gombart, A. F., T. Saito, and H. P. Koeffler. 2009. Exaptation of an ancient Alu short interspersed element provides a highly conserved vitamin D-mediated innate immune response in humans and primates. BMC Genomics 10:321.

Haussler, M. R., G. K. Whitfield, I. Kaneko, C. A. Haussler, D. Hsieh, J. C. Hsieh, and P. W. Jurutka. 2013. Molecular mechanisms of vitamin D action. Calcif. Tissue Int. 92:77-98.

Hoe, E., J. Nathanielsz, Z. Q. Toh, L. Spry, R. Marimla, A. Balloch, K. Mulholland, and P. V. Licciardi. 2016. Anti-inflammatory effects of vitamin D on human immune cells in the context of bacterial infection. Nutrients 8:E806.

Horst, R. L., J. P. Goff, and T. A. Reinhardt. 2005. Adapting to the transition between gestation and lactation: Differences between rat, human and dairy cow. J. Mammary Gland Biol. Neoplasia 10:141-156.

Hussen, J., C. Frank, A. Düvel, M. Koy, and H. J. Schuberth. 2014. The chemokine CCL5 induces selective migration of bovine classical monocytes and drives their differentiation into LPS-hyporesponsive macrophages in vitro. Dev. Comp. Immunol. 47:169-177.

Ibeagha-Awemu, E. M., J. W. Lee, A. E. Ibeagha, D. D. Bannerman, M. J. Paape, and X. Zhao. 2008. Bacterial lipopolysaccharide induces increased expression of toll-like receptor (TLR) 4 and downstream TLR signaling molecules in bovine mammary epithelial cells. Vet. Res. 39:11.

Jones, G., D. E. Prosser, and M. Kaufmann. 2014. Cytochrome P450mediated metabolism of vitamin D. J. Lipid Res. 55:13-31.

Kopp, E., and R. Medzhitov. 2003. Recognition of microbial infection by Toll-like receptors. Curr. Opin. Immunol. 15:396-401.

Lippolis, J. D., T. A. Reinhardt, J. P. Goff, and R. L. Horst. 2006 Neutrophil extracellular trap formation by bovine neutrophils is not inhibited by milk. Vet. Immunol. Immunopathol. 113:248-255.

Lippolis, J. D., T. A. Reinhardt, R. A. Sacco, B. J. Nonnecke, and C. D. Nelson. 2011. Treatment of an intramammary bacterial infection with 25-hydroxyvitamin D(3). PLoS One 6:e25479.

Liu, P. T., S. R. Krutzik, and R. L. Modlin. 2007a. Therapeutic implications of the TLR and VDR partnership. Trends Mol. Med. $13: 117-124$

Liu, P. T., M. Schenk, V. P. Walker, P. W. Dempsey, M. Kanchanapoomi, M. Wheelwright, A. Vazirnia, X. Zhang, A. Steinmeyer, U. Zugel, B. W. Hollis, G. Cheng, and R. L. Modlin. 2009 Convergence of IL-1beta and VDR activation pathways in human TLR2/1-induced antimicrobial responses. PLoS One 4:e5810.

Liu, P. T. S. Stenger, H. Li, L. Wenzel, B. H. Tan, S. R. Krutzik, M. T. Ochoa, J. Schauber, K. Wu, C. Meinken, D. L. Kamen, M. Wagner, R. Bals, A. Steinmeyer, U. Zugel, R. L. Gallo, D. Eisenberg, M. Hewison, B. W. Hollis, J. S. Adams, B. R. Bloom, and R. L. Modlin. 2006. Toll-like receptor triggering of a vitamin D-mediated human antimicrobial response. Science 311:1770-1773.

Liu, P. T., S. Stenger, D. H. Tang, and R. L. Modlin. 2007b. Cutting edge: Vitamin D-mediated human antimicrobial activity against Mycobacterium tuberculosis is dependent on the induction of cathelicidin. J. Immunol. 179:2060-2063.

Mackenzie-Dyck, S., S. Attah-Poku, V. Juillard, L. A. Babiuk, and S. van Drunen Littel-van den Hurk. 2011. The synthetic peptides bovine enteric $\beta$-defensin (EBD), bovine neutrophil $\beta$-defensin (BNBD) 9 and BNBD 3 are chemotactic for immature bovine dendritic cells. Vet. Immunol. Immunopathol. 143:87-107.

Mayne, C. G., J. A. Spanier, L. M. Relland, C. B. Williams, and C. E. Hayes. 2011. 1,25-Dihydroxyvitamin D3 acts directly on the T lymphocyte vitamin D receptor to inhibit experimental autoimmune encephalomyelitis. Eur. J. Immunol. 41:822-832.

McCollum, E. V., N. Simmonds, J. E. Becker, and P. G. Shipley. 1922. Studies on experimental rickets. XXI. An experimental demonstration of the existence of a vitamin which promotes calcium deposition. J. Biol. Chem. 53:293-312.

Merriman, K. E., M. F. Kweh, J. L. Powell, J. D. Lippolis, and C. D. Nelson. 2015. Multiple $\beta$-defensin genes are upregulated by the vitamin D pathway in cattle. J. Steroid Biochem. Mol. Biol. 154:120-129. 
Merriman, K. E., M. B. Poindexter, M. F. Kweh, J. E. Santos, and C. D. Nelson. 2017. Intramammary 1,25-dihydroxyvitamin D3 treatment increases expression of host-defense genes in mammary immune cells of lactating dairy cattle. J. Steroid Biochem. Mol. Biol. 173:33-41.

Merriman, K. E., J. L. Powell, J. E. P. Santos, and C. D. Nelson. 2015. Intramammary 25-hydroxyvitamin $\mathrm{D}_{3}$ treatment increases vitamin D pathway activity but not acute host-defense responses to endotoxin-induced mastitis. Proceedings Conference of Research Workers in Animal Diseases Annual Meeting, Abstract 105, http://www crwad.org.

Nashold, F. E., C. D. Nelson, L. M. Brown, and C. E. Hayes. 2013. One calcitriol dose transiently increases Helios+ FoxP3+ T cells and ameliorates autoimmune demyelinating disease. J. Neuroimmunol. 263:64-74.

Nelson, C. D., B. J. Nonnecke, T. A. Reinhardt, W. R. Waters, D. C. Beitz, and J. D. Lippolis. 2011. Regulation of Mycobacterium-specific mononuclear cell responses by 25-hydroxyvitamin $\mathrm{D}_{3}$. PLoS One 6:e21674.

Nelson, C. D., T. A. Reinhardt, D. C. Beitz, and J. D. Lippolis. 2010a. In vivo activation of the intracrine vitamin $\mathrm{D}$ pathway in innate immune cells and mammary tissue during a bacterial infection. PLoS One 5:e15469.

Nelson, C. D., T. A. Reinhardt, J. D. Lippolis, R. E. Sacco, and B. J. Nonnecke. 2012. Vitamin D signaling in the bovine immune system: A model for understanding human vitamin D requirements. Nutrients 4:181-196.

Nelson, C. D., T. A. Reinhardt, T. C. Thacker, D. C. Beitz, and J. D. Lippolis. 2010b. Modulation of the bovine innate immune response by production of 1alpha,25-dihydroxyvitamin $\mathrm{D}(3)$ in bovine monocytes. J. Dairy Sci. 93:1041-1049.

NRC. 2001. Nutrient Requirements of Dairy Cattle. 7th rev. ed. National Academy Press, Washington, DC.

Oliver, S. P., and S. E. Murinda. 2012. Antimicrobial resistance of mastitis pathogens. Vet. Clin. North Am. Food Anim. Pract. $28: 165-185$.

Pike, J. W., and M. B. Meyer. 2014. Fundamentals of vitamin D hormone-regulated gene expression. J. Steroid Biochem. Mol. Biol. 144 Pt A:5-11.

Rainard, P., and C. Riollet. 2006. Innate immunity of the bovine mammary gland. Vet. Res. 37:369-400.

Riollet, C., P. Rainard, and B. Poutrel. 2000. Cells and cytokines in inflammatory secretions of bovine mammary gland. Adv. Exp. Med. Biol. 480:247-258.

Ruegg, P. L. 2012. Mastitis in dairy cows. Vet. Clin. North Am. Food Anim. Pract. 28:xi-xii.

Ryman, V. E., N. Packiriswamy, B. Norby, S. E. Schmidt, A. L. Lock, and L. M. Sordillo. 2017. Supplementation of linoleic acid (C18: $2 \mathrm{n}-6)$ or $\alpha$-linolenic acid (C18:3n-3) changes microbial agonist-induced oxylipid biosynthesis. J. Dairy Sci. 100:1870-1887.

Sadeghi, K., B. Wessner, U. Laggner, M. Ploder, D. Tamandl, J. Friedl, U. Zügel, A. Steinmeyer, A. Pollak, E. Roth, G. Boltz-Nitulescu, and A. Spittler. 2006. Vitamin D3 down-regulates monocyte TLR expression and triggers hyporesponsiveness to pathogen-associated molecular patterns. Eur. J. Immunol. 36:361-370.

Samuchiwal, S. K., B. Balestrieri, H. Raff, and J. A. Boyce. 2017. Endogenous prostaglandin E2 amplifies IL-33 production by macrophages through an E prostanoid (EP)2/EP4-cAMP-EPAC-dependent pathway. J. Biol. Chem. 292:8195-8206.

Schmitz, S., M. W. Pfaffl, H. H. Meyer, and R. M. Bruckmaier. 2004. Short-term changes of mRNA expression of various inflammatory factors and milk proteins in mammary tissue during LPS-induced mastitis. Domest. Anim. Endocrinol. 26:111-126.

Selsted, M. E., Y. Q. Tang, W. L. Morris, P. A. McGuire, M. J. Novotny, W. Smith, A. H. Henschen, and J. S. Cullor. 1993. Purification, primary structures, and antibacterial activities of beta-defensins, a new family of antimicrobial peptides from bovine neutrophils. J. Biol. Chem. 268:6641-6648.

Sommerfeldt, J. L., J. L. Napoli, E. T. Littledike, D. C. Beitz, and R. L. Horst. 1983. Metabolism of orally administered [3H]ergocalciferol and $[3 \mathrm{H}]$ cholecalciferol by dairy calves. J. Nutr. 113:2595-2600.

Sordillo, L. M., and K. L. Streicher. 2002. Mammary gland immunity and mastitis susceptibility. J. Mammary Gland Biol. Neoplasia $7: 135-146$.

Téllez-Pérez, A. D., N. Alva-Murillo, A. Ochoa-Zarzosa, and J. E. López-Meza. 2012. Cholecalciferol (vitamin D) differentially regulates antimicrobial peptide expression in bovine mammary epithelial cells: Implications during Staphylococcus aureus internalization. Vet. Microbiol. 160:91-98.

Wang, F., R. L. Johnson, M. L. DeSmet, P. W. Snyder, K. C. Fairfax, and J. C. Fleet. 2017. Vitamin D receptor-dependent signaling protects mice from dextran sulfate sodium-induced colitis. Endocrinology 158:1951-1963.

Wang, T. T., F. P. Nestel, V. Bourdeau, Y. Naga, Q. Wang, J. Liao, L. Tavera-Mendoza, R. Lin, J. W. Hanrahan, S. Mader, and J. H. White. 2004. Cutting edge: 1,25-dihydroxyvitamin D3 is a direct inducer of antimicrobial peptide gene expression. J. Immunol. 173:2909-2912.

Wang, T. T., L. E. Tavera-Mendoza, D. Laperriere, E. Libby, N. B. MacLeod, Y. Nagai, V. Bourdeau, A. Konstorum, B. Lallemant, R. Zhang, S. Mader, and J. H. White. 2005. Large-scale in silico and microarray-based identification of direct 1,25-dihydroxyvitamin $\mathrm{D}_{3}$ target genes. Mol. Endocrinol. 19:2685-2695.

Waters, W. R., B. J. Nonnecke, T. E. Rahner, M. V. Palmer, D. L. Whipple, and R. L. Horst. 2001. Modulation of Mycobacterium bovis-specific responses of bovine peripheral blood mononuclear cells by 1,25-dihydroxyvitamin D(3). Clin. Diagn. Lab. Immunol. 8:1204-1212.

Yue, Y., L. Hymøller, S. K. Jensen, C. Lauridsen, and S. Purup. 2017. Effects of vitamin D and its metabolites on cell viability and Staphylococcus aureus invasion into bovine mammary epithelial cells. Vet. Microbiol. 203:245-251.

Zhang, Y., D. Y. Leung, B. N. Richers, Y. Liu, L. K. Remigio, D. W. Riches, and E. Goleva. 2012. Vitamin D inhibits monocyte/macrophage proinflammatory cytokine production by targeting MAPK phosphatase-1. J. Immunol. 188:2127-2135. 